\title{
Resilience of African migrants: an integrative review
}

\section{Authors:}

*Olutoyin Babatunde-Sowole RN BN (Hons), RM Dip/Masters Mid

Faculty of Health, University of Technology Sydney

PO Box 123, Broadway, NSW, 2007, Australia

Email: Olutoyin.0.Sowole@student.uts.edu.au

Phone: +61423019608

Tamara Power RN, PhD

Faculty of Health, University of Technology Sydney

PO Box 123, Broadway, NSW, 2007, Australia

Email: Tamara.Power@uts.edu.au

Debra Jackson RN, PhD

Faculty of Health, University of Technology Sydney

Faculty of Health \& Life Sciences, Oxford Brookes University, UK

Email: djackson@brookes.ac.uk

Patricia M Davidson RN, PhD

Centre for Cardiovascular and Chronic Care

Faculty of Health, University of Technology Sydney

PO Box 123, Broadway, NSW, 2007, Australia

Johns Hopkins University School of Nursing, Baltimore, Maryland, USA

Email: pdavidson@jhu.edu

Michelle DiGiacomo PhD

Centre for Cardiovascular and Chronic Care

Faculty of Health, University of Technology Sydney

PO Box 123, Broadway, NSW 2007, Australia

Email: michelle.digiacomo@uts.edu.au

\section{*Corresponding author}

Authors' declaration: The authors confirm that this manuscript, in whole or part, has not been published elsewhere and that it has not been submitted simultaneously for publication elsewhere.

The authors have no conflicts of interest to declare.

Running head: African migrant resilience 


\section{Resilience of African migrants: an integrative review}

In a world currently marked by dynamic demographic changes through international migration, it is important to understand how migrants adapt to migration and acculturation experiences and demonstrate resilience in their host countries. Until recently, there has been little focus on African migrant women's resilience, yet they are a prominent and influential group within their communities. The purpose of this review was to ascertain factors and characteristics of African women's resilience in the context of migration. Understanding more about African women's resilience can be a valuable resource for health care professionals who can support health and wellbeing in women, their families, and new communities.

Emerging data over the past decades suggest that migration research could benefit from using a strengths-based approach, such as resilience, in understanding the experiences of migrants (Hutchinson \& Dorsett, 2012). Whilst there has been some documentation of resilience of migrant women in European and North American studies (Çakir, 2009; Cakir \& Yerin Guneri, 2011; Chung, Hong, \& Newbold, 2013), less is known about the resilience and strength of African migrant women. Migrants include refugees from war-torn areas and voluntary immigrants. Voluntary immigrants are essentially skilled migrants who leave their country in search of employment opportunities (Pottie, Ng, Spitzer, Mohammed, \& Glazier, 2008).

The percentage of women migrating internationally is greater than their male counterparts. By 2009, women comprised over 60\% of all migrants worldwide (United Nations Department of Economic and Social Affairs Population Division, 2009). War and government instability in parts of Africa are increasingly leading to more women becoming international asylum seekers, refugees and migrants to the Western world. The number of African people migrating to the United States of America (USA) outnumbered those from Europe, Asia and Latin America (Blankson, Spears, \& 
Hinson, 2012; Logan, 2009). The Canadian census in 2009 also showed an increased rate of African migrants (Statistics Canada, 2009). In the United Kingdom (UK), the numbers of African migrants are even greater, perhaps due to its proximity to the African continent. In 2008, the African-born population in the UK was approximately 0.5 million at an 855 male to 1000 female ratio (United Kingdom National Statistics, 2009). A significant increase in numbers of African people arriving into Australia (Abdelkerim \& Grace, 2012; Khan \& Pedersen, 2010) and New Zealand may be due to the adoption of the refugee quota systems as well as a rise in skilled immigrant intake into these countries (Adelowo, 2012). Women are also being increasingly resettled under the "Women and Girls at Risk" program in Western countries under the United Nations High Commission for Refugees (UNHCR) (Guerin, Allotey, Elmi, \& Baho, 2006). Under this scheme, Europe, Canada, USA, Australia, and New Zealand agree to receive asylum-seekers, of whom 47\% of refugees in 2010 were girls and women (United Nations High Commissioner for Refugees, 2012).

Despite the increasing migration of African people, particularly African women, there is little research depicting their resilience. Resilience is crucial to basic human existence and survival; and for the purpose of this paper, resilience is conceptualised as the ability to overcome life challenges and transform such challenges into positive growth (Gillespie, Chaboyer, \& Wallis, 2007). The aim of our paper was to ascertain factors associated with resilience and strength of African migrant women.

Historically, Africa and its peoples have been represented as a 'dark continent', marked by disease, war, and famine (Obrist \& Büchi, 2008; Poncian, 2015). Stigmatized conditions and practices pervade the literature describing African people. Such studies investigate the effects of infectious diseases such as HIV/AIDS (Drummond, Mizan, \& Wright, 2008) and female genital mutilation (Berg \& Denison, 2013; Bjälkander et al., 2012; Browne, 2014). Also frequently explored are chronic diseases such as obesity, cardiovascular disease (Drummond, Mizan, Burgoyne, \& Wright, 
2011; Hall, Thomsen, Henriksen, \& Lohse, 2011), intimate partner violence (Akinsulure-Smith, M, Chu, Keatley, \& Rasmussen, 2013; Ogunsiji, Wilkes, Jackson, \& Peters, 2011) and mental illness caused by trauma and adversity during the migration process (Schweitzer, Melville, Steel, \& Lacherez, 2006; Venters et al., 2011). Migration has also been documented as contributing to the incidence of postpartum depression among African migrant mothers in Australia (Murray, Windsor, Parker, \& Tewfik, 2010).

In some cases, negative stereotypes about African migrants have resulted in barriers to health services. For example, African residents who were living in Victoria, Australia, were restricted from participating in blood donation because of the perception that the broader community of Africans carry blood-borne diseases or have a tropical disease (Polonsky, Brijnath, \& Renzaho, 2011). Such an outcome may restrict the possibility of successful treatment for patients of African descent who need compatible blood products (McQuilten, Waters, Polonsky, \& Renzaho, 2014). Arthur (2009) also documented evidence of racism experienced by African migrant women in the USA. Researchers found that migrant women face more racism and discrimination than men and have less access to economic resources and English language skills improvement (Remennick, 2005).

In spite of the stress of migrating and adapting to living in a new country, it is vital to highlight that many migrant women are resilient as they reestablish their lives in a new culture (Kuo, 2014). In this paper, we review examine literature on resilience and how African migrants report their adaptation to a new culture. Our review includes both African women and men due to the dearth of studies on the resilience of migrant women. We argue that the ways in which resilience is enacted by African migrants, and their capability to face migration challenges, is critical knowledge for the international research audience. Resilience strategies enacted by African migrant women, in particular, represent a valuable resource for ensuring wellbeing in women, their families, and new communities. 


\section{Methods}

We conducted an integrative literature review using a systematic approach and the Preferred Reporting Items for Systematic Meta-Analysis framework [PRISMA] (Moher, Liberati, Tetzlaff, \& Altman, 2009) to identify factors influencing, and strategies for, developing resilience in African migrant women. For quality appraisal purposes, the included papers were reviewed for design, sample, setting, data collection method and analysis, clarity of writing, generalizability and reflexivity. This approach has been used successfully by other researchers (McGarry, Simpson, \& Hinchliff-Smith, 2011; Robinson \& Spilsbury, 2008) as adapted from Mays and Pope (2000).

Search strategy

Between May and June 2014, electronic databases including Academic Search Complete (Ebsco), Scopus, Cumulative Index to Nursing and Allied Health Literature (CINAHL), Medline (Ovid), PsychInfo, and Multicultural Australia and Immigration Studies [MAIS], were searched for peerreviewed material published between 2004-2014. Boolean terms were derived in consultation with a health librarian. Our search terms were keywords and derivatives of 'Africa*'; 'women*'; 'migrant*'; 'immigrants*'; 'refugee*'; strength* and 'resilien*'. Additionally, we searched the grey literature with variations of the same keywords. The Social Science Research Network and the Google search engine were used to access grey literature. Additional material was sourced by manual hand searching of reference lists.

\section{Eligibility criteria}

Articles were included if they explored the resilience of African migrant women or their adaptive strategies. Due to the paucity of literature, identified articles reporting on both men and women were included, although we aimed to focus on African migrant women. We included papers written 
in English, published in peer-reviewed or grey literature (reports and theses) and containing participants aged 18 and over. All study designs were included. Studies were excluded if they mainly focused on psychopathology or trauma experienced by participants, or if resilience or strength was not discussed. We excluded conference abstracts, book reviews, and research depicting internally displaced people, African American, or African Caribbean populations.

\section{Evaluation and analysis}

We extracted data reflecting author/year, country/setting, population, study design and aims from the collected literature and entered it into a spreadsheet to facilitate analysis (Tables 1 and 2). We used a critical appraisal tool to systematically evaluate the peer-reviewed journal articles. As there are no formal methods for weighing appraisals in integrative reviews, none were undertaken during this process. We used an adapted version of Bronfenbrenner's ecological model (Bronfenbrenner, 1979; Bronfenbrenner, 1989; Mental Health Foundation of Australia [MHFA], 2005) (Figure 1) to organise the findings and examine the interactive processes between migrants and their environment and between the risks and protective factors. Internal and external factors interact and influence resilience. Complexities in these interactive relationships depict the human environment, particularly for migrant people. The framework also depicts links between the person's inner resources, family resources, external systems and the larger environment that are capable of affecting resilience and wellbeing (Hetherington \& Stanley-Hagan, 2002; Wise, 2003). The adaptation of the ecological framework is novel in the study of this cohort and migration literature.

\section{INSERT FIGURE 1 HERE}

\section{Results}


We included fifteen articles in the review (Figure 2). The articles were primarily qualitative (n=14) and published in peer-reviewed journals $(n=9)$. Six grey literature documents were included. All studies consisted of experiences and displays of resilience by study participants. The literature predominantly centered on experiences of refugees from East, Central, and Northern Africa. Some studies included people from non-African countries based on the view that they were also refugees. The sample sizes ranged from four (Lenette, Brough, \& Cox, 2013) in an Australian study to a UK study of 62 African people (Anderson \& Doyal, 2004). There were 112 women documented as participating in these studies, although 4 articles did not provide numbers of women contributors. A methodological challenge during the search was the lack of clear definition of resilience; instead, it was often used interchangeably with coping, adaptation, and 'helps'. We did not reject papers that met inclusion criteria due to poor quality.

\section{INSERT FIGURE 2 HERE}

\section{INSERT TABLE 1 \& TABLE 2 HERE}

\section{Findings}

\section{Strategies for resilience}

\section{Internal factors}

The internal or personal factors are represented in the microsystem level of Bronfenbrenner's framework. These are thoughts and behaviours as well as personal values and skills of the participants (Mental Health Foundation of Australia, 2005), which are used to maintain equilibrium and achieve positive outcomes during the migration and resettlement challenges. 
Personal qualities and inner strength of the participants were depicted in different ways. For example, cognitive strategies were used by North African Sudanese men and women (Schweitzer, Greenslade, \& Kagee, 2007). For these people, achieving cognitive resilience was explained in relation to educational and employment accomplishments. Khawaja, White, Schweitzer and Greenslade, (2008) explained that the North African participants used cognitive strategies to mentally reconstruct the migration stress in relation to their current achievement and growth and acceptance of difficult situations while having an aspirational focus.

Sudanese refugees reported enacting social comparisons to assist in adapting to life in Australia (Schweitzer et al., 2007). The participants were able to appreciate freedom in Australia when comparing their own situation to others still in Africa and refugees currently being held in Australian detention centres. Other researchers highlighted personal resources such as hopes and goals, having a positive attitude, using spirituality or religiosity that involved prayer and faith, and the individual's sense of growth and strength (Adelowo, 2012; Anderson \& Doyal, 2004; Khawaja et al., 2008; Orton, Griffiths, Green, \& Waterman, 2012; Shakespeare-Finch \& Wickham, 2010).

\section{Spirituality and Faith}

Spirituality and religiosity were vital sources of strength and resilience in many of the studies. This included faith in a 'Higher Being' or in traditional myths and folkloric beliefs (Adelowo, 2012; Obrist \& Büchi, 2008). In one study, participants undertook religious activities that included cleansing rituals during travels to their homelands to protect their health and for continual strength to overcome their migration challenges (Obrist \& Büchi, 2008). Shakespeare-Finch and Wickham (2010) found that refugees' belief in God through prayer and faith helped them to stay strong and endure trauma and resettlement stressors in Australia. As one of the participants said "I'm praying rather than just get sad..." (Shakespeare-Finch \& Wickham, 2010, p. 38). Likewise, women's reports 
of their HIV status revealed extraordinary resilience in the face of disease and residency status (Anderson \& Doyal, 2004). The women in the Anderson and Doyal (2004) study drew strength from their religious and spiritual beliefs in staying strong through their HIV experiences. Schweitzter et al (2007) found that spiritual beliefs also instilled a sense of control and will to live in Sudanese participants.

US researchers suggested a possible difference in the way that spirituality or religious beliefs impact on migrants (Bentley, Ahmad, \& Thoburn, 2014). In their quantitative study of 59 Somali refugee Muslims from East Africa, Bentley et al. (2014) found that participants' religious practices did not protect them against post-traumatic stress disorders resulting from experiencing war and torture prior to migrating to America. According to the authors, the relationship between trauma and religiosity was important in the studied group, however, the quantitative study design limited capacity to collect contextual information that may have explained responses.

\section{External factors}

The external factors are represented in the model as the meso-, exo-, and macro-systems level characteristics (Figure 1). These levels involve constructs of family and associated values, norms, and expectations (Mental Health Foundation of Australia, 2005). In addition, the factors involve the local and wider communities of the migrants, which they used to help maintain equilibrium and achieve positive outcomes during the migration and resettlement.

\section{Communalism}

Communalism is central to Afro-cultural ethos (Mbiti, 1970). The West African axiom 'I am because we are' and 'since we are, therefore I am' (Mbiti, 1970, p. 141) illustrates the essence of communalism. It indicates interdependence and that the individual is responsibly linked to others 
in their social milieu (Boykin, Jagers, Ellison, \& Albury, 1997). Communalism was a prominent factor highlighted in the reviewed studies. The sense of communalism was intertwined with the support that some of the participants received in achieving resilience to adapt to life in their new country. Despite being from different African countries, being African was a communal bond. One Sudanese participant stated that “...so many different people came from Africa...we become brothers, so everything we just cooperate together..." (Shakespeare-Finch \& Wickham, 2010, p. 38).

Communalism was also used by the African women in a New Zealand study (Adelowo, 2012) who reported developing resilience by remaining connected to their home countries, as well as associating with other migrant women in New Zealand. Additionally, the women utilised support from families, established connections at work, and accessed available New Zealand government support. Some of the participants stayed in touch with their homeland, not only for support but also to fulfill their social duties of providing financial and material aid to those remaining in their countries of origin (Adelowo, 2012; Obrist \& Büchi, 2008).

Food represented communal ties and eating African dishes was another way of keeping their memories of home alive (Adelowo, 2012; Obrist \& Büchi, 2008). Others indicated that being connected to the local ethnic community groups and churches provided support during difficult periods (Adelowo, 2012). Many of the women recognised the relationships they developed with people in their new country reduced their feelings of isolation.

Participants' use of technology was another reported form of communalism (Adelowo, 2012;

Khawaja et al., 2008; Obrist \& Büchi, 2008). Strategies for resilience in the context of migration challenges involved making efforts to stay in touch with friends and relatives, through communication technologies like SMS, email and Skype. Striving to live in harmony with others and 
accessing carer support as provided by the government were other documented resilience strategies (Adelowo, 2012; Anderson \& Doyal, 2004; Orton et al., 2012).

Communalism was also implicated in knowledge levels among some African refugees. The 20 participants in Lloyd's (2014) study, who were mainly African refugees living in Wagga Wagga, Australia, displayed communalism in building understanding about health in their new country through knowledge and information pooling. Knowledge and information pooling is a process whereby the fragments of knowledge that the migrants possess are pooled together to create a more comprehensive picture of a situation and shared (Lloyd, 2014). Lloyd (2014) highlighted that the process was a meaningful, purposeful and culturally congruent collective adaptation strategy in the use of health services and health literacy.

\section{Empowerment}

The ability of the migrants to become empowered in their lives individually and as a community, relative to the stressors and trauma of migration, was vital. The African migrants' resilience drove them to establish associations for networking to resist marginalization while encouraging their integration into the new country's culture (Bailey, 2012; De Tona \& Lentin, 2010). Mwanri Hiruy and Masika (2012) also highlighted the need to empower new African refugees as a community to build their resilience, and further discussed how an empowered community offers their individual members the opportunity to use their skills and resources to collectively meet community needs (Mwanri et al., 2012).

The external sources of strength and resilience also included social support. Participants in several studies reported sourcing support from family, making friends and becoming a part of the local community, and through acculturation and or financial settlement assistance provided to them by government (Adelowo, 2012; Schweitzer et al., 2007; Shakespeare-Finch \& Wickham, 2010). 
However, the strong sense of determination and optimism in eleven Rwandan refugee university students shaped the way in which they viewed the available social support differently (Webb, 2013). Seeing themselves as regular students requiring no special treatment on the campus, these Rwandan refugees resisted using and becoming dependent on the accessible refugee support within the university.

Researchers described developing resilience as a dynamic process because it is inherently social, involving not only a person's inner resources, but also external resources (Lenette et al., 2013; Obrist \& Büchi, 2008). Lenette et al. (2013) discussed the resilience of the four Sudanese single parents in their study as being person-environment connected. The resilience discussion in all of the reviewed articles depicted that the internal and external factors that were interwoven rather than operating in isolation. This attests to the usefulness of the ecological framework for this review (Adelowo, 2012; Lenette et al., 2013; Lloyd, 2014; Schweitzer et al., 2007; ShakespeareFinch \& Wickham, 2010).

\section{Discussion}

In this review, we have highlighted the resilience of African migrants, which is vital given the increasing international migration to other countries around the globe. The evidence can be used to assist health care professionals working with African migrants, to develop resilience in Western countries. Nearly all of the included studies in this review were heterogeneous in terms of populations and gender, which limits the application and generalizability of results. Most of the reviewed articles were published within the previous five years, which underscores the relatively recent emphasis on resilience of African migrants.

We learned from the reviewed literature that African migrants' resilience involves cognitive strategies and communalism. These elements are consistent with previous findings in the 
migration literature. Emphasising the importance of support through a qualitative study, the domestic women workers from the Philippines in van der Ham's (2014) study, identified social support as significant factor in the development of their personal strengths and resilience to migration experiences. In addition to receiving support from friends and family, people access support from their ethnic communities to overcome challenges. Correa-Velez, Gifford and Barnett, (2010) discussed the desire of the refugees in their study in integrating with their ethnic community as a form of support because it boosted their levels of morale and well-being. The refugees were 97 youths living in Melbourne, Australia, originating from 11 different countries including 68\% born in Africa, 27\% Middle East, and the remaining 5\% born in Eastern Europe and Southeast Asia. They were all attending English language schools as recently arrived refugees.

In a qualitative study of immigrant women's resilience in Canada, Rashid and Gregory (2014) found that immigrant women used cognitive strategies and personal resilience to overcome migration adversities. All four women were professionally educated prior to migration, but two of them could not secure employment that aligned with their educational qualifications. Consistent with the literature in this review, the women in Rashid and Gregory's (2014) study engaged in further education to improve their employability by undertaking language and computer skills for improved career prospects.

Religious beliefs and spirituality have been reported as useful in overcoming diverse issues in migrants' lives. As explained in the literature, women see faith and spirituality as a strong source of resilience; because it creates a base upon which to plan their futures and provides the capacity to make meaning of their migration settlement challenges (Gladden, 2012; Kalathil, Bhakta, Daniel, Joseph, \& Trivedi, 2011). Religion has been well documented as a common source of resilience for African refugees (Sherwood \& Liebling-Kalifani, 2013). Religiosity and spirituality, which is often demonstrated through personal beliefs and value systems, were also evident among the Mexican 
Latino immigrants in the USA in achieving positive resettlement and acculturation and reducing acculturation challenges (Sanchez, Dillon, Concha, \& De La Rosa, 2014; Steffen \& Merrill, 2011). The importance of religiosity and faith in shaping and building the resilience capacity of African migrants cannot be overemphasized. Healthcare workers may be well-positioned to support migrants' integration of experiences and adjustment (Gladden, 2012).

Empowerment is a key outcome of resilience. Similar empowerment for migrants was explicated in a study that explored the lives of Turkish migrant women who positively reestablished themselves into a new culture (Cakir and Guneri, (2011). Additionally, it has been documented that African women are strengthened and empowered if given the opportunity to verbalise their experiences and or emotions (Clare, Goodman, Liebling, \& Laing, 2014; Sherwood \& Liebling-Kalifani, 2013). Likewise, listening to African migrant women's stories is foundational in planning social change for tackling the gender inequalities and health problems that the social status of these women may entail (Pavlish, 2005).

In their study that looked at the protective nature of Afrocentric worldview while comparing the perceived stress and psychological functioning of 112 African American young adults, Neblett, Hammond, Seaton and Townsend (2010) found that spirituality, positive affect, and communalism [Afrocentric worldview] operate as source of resilience and achieving adaptive outcomes to stressful situations and other negative circumstances.

Successful communication is vital for the effective use of healthcare and knowledge transfer among migrants to achieve positive adaptation. The use of knowledge pooling in achieving resilience is an important aspect of the findings. The stress and adversity of re-establishment into a new culture served as a motivator for information seeking for the participants in Lloyd's (2014) study. The resilience of African migrants in the literature reviewed has demonstrated the diverse contribution 
from various fields in achieving resilience of migrants. For example, as explained by Hersberger (2013), the contribution of library and information services to resilience is vital. In recognising people with negative life experiences, Hersberger (2013) believes that library personnel's knowledge of the concept of resilience can advance the services provided to their patrons whose negative experiences can impact the information that they seek. In another paper, the authors emphasized the power of knowledge and information for new settlers into a new country, especially because of the information landscapes that may not only be new, but could also be complex and difficult to navigate (Kennan, Lloyd, Qayyum, \& Thompson, 2011). Information that new settlers may seek includes how to access basic needs such as housing, employment, education and health. In this scenario, the library and information services become useful. The information may also assist the new arrivals to become information rich and socially included in their new countries.

In accordance with the conceptual framework, considering the migration experience within the context of the host culture is important in the lives of African migrants. Essentially, our review has drawn attention to the paucity of research centering on Australian-dwelling West African migrant women's resilience. Discussion of the strength and resilience of voluntary migrants has, thus far, been minimal. Most research we located during our review focused on refugees. For example, Sudanese refugees are well-studied, likely because of lengthy periods of conflict that resulted in the displacement of many into the developed world. Yet, the North African Sudanese are not a homogenous group (Tempany, 2009). Additionally, the amount of study on the North African Sudanese group might have skewed the research worldview of the African people. The majority of research on refugees, in general, centers on psychopathology rather than resilience in their migration stories (Hutchinson \& Dorsett, 2012). 
Kanyoro suggests that the empowering of the African migrant community is important (2002).

Referred to as community hermeneutics, it is a process of creating community awareness about concepts such as patriarchy that are capable of diminishing African women from using agency to achieve resilience in difficult times (Kanyoro, 2002; Pavlish, 2005).

We applied an adapted Bronfenbrenner ecological model in this review to demonstrate how supportive environments contribute to the inherent resilience in African migrant women as well as the significance of context in achieving migrant resilience (Bronfenbrenner, 1979; Graham, 2011). The inter-dependence of each systems level - micro, meso, exo, and macro can facilitate healthy environments for human resilience, therefore the resilience of migrants rests heavily on the strength of all elements of the system. The ecological model has strengthened this paper by highlighting the importance of the government in providing services and resources to migrants in their resettlement which can help to reduce blame on the migrants for their circumstances by others (Pulvirenti \& Mason, 2011). Additionally, our use of the framework attests to the fact that migrant resilience is achieved with support of external sources including the wider community beyond just friends, families or their own ethnic communities (Pulvirenti \& Mason, 2011). The adaptation of the Bronfenbrenner framework to this review also increases our understanding that the strengthening of human relationships within a nurtured environment is a positive step towards achieving and increasing resilience of migrants. Therefore, nurses, midwives and allied workers caring for migrant women could consider adopting the framework to inform their contact with migrant people.

\section{Limitations}

This review is a general discussion of African migrants. Further research into people from specific regions of the African Continent may assist in exploring convergence and divergence of issues 
presented. Although the population of interest in our study was women, the paucity of literature necessitated the inclusion of studies that included men. We were unable to examine just the women's experiences separate to those of men; which disallowed a focus on the gendered experience of migration. For future research, it will be valuable to explore literature on African men's resilience and compare and contrast outcomes with women. A number of articles were excluded due to their focus on psychopathology. Additionally, due to our requirement that papers be written in English and the focus be on migrants entering developed/industrialised nations of the world, other relevant works may have been excluded.

\section{Conclusions}

Women derive a number of sources of support from families, communities and the wider societies around them. This_review highlighted the ways resilience is enacted by African migrants and their capability to face migration challenges. The importance of African migrants' resilience to the welfare and healthy settlement of their families into a new culture, and indeed the benefits to the new communities, cannot be overemphasized. 


\section{References}

Abdelkerim, A. A., \& Grace, M. (2012). Challenges to employment in newly emerging African communities in Australia: A review of the literature. Australian Social Work, 65(1), 104-119.

Adelowo, A. (2012). The adjustment of African women living in New Zealand: a narrative study. (Ph.D thesis Unpublished Ph.D), School of Health Care Practice, Auckland University of Technology, New Zealand, Auckland University of Technology, 228 pages.

Akinsulure-Smith, M, A., Chu, T., Keatley, E., \& Rasmussen, A. (2013). Intimate Partner Violence among West African Immigrants. Journal of aggression, maltreatment \& trauma, 22(2), 109-126.

Anderson, J., \& Doyal, L. (2004). Women from Africa living with HIV in London: a descriptive study. AIDS care, 16(1), 95-105.

Arthur, J. A. (2009). African Women Immigrants in the United States: Palgrave Macmillan.

Bailey, O. G. (2012). Migrant African women: tales of agency and belonging. Ethnic and Racial Studies, 35(5), 850-867.

Bentley, J., Ahmad, Z., \& Thoburn, J. (2014). Religiosity and posttraumatic stress in a sample of East African refugees. Mental Health, Religion \& Culture, 17(2), 185-195. doi: $10.1080 / 13674676.2013 .784899$

Berg, R. C., \& Denison, E. (2013). A tradition in transition: factors perpetuating and hindering the continuance of female genital mutilation/cutting (FGM/C) summarized in a systematic review. Health care for women international, 34(10), 837-859. 
Bjälkander, O., Bangura, L., Leigh, B., Berggren, V., Bergström, S., \& Almroth, L. (2012). Health complications of female genital mutilation in Sierra Leone. International journal of women's health, 4, 321.

Blankson, C., Spears, N., \& Hinson, R. E. (2012). West African Immigrants' Perceptions of Advertising in General and Impact on Buying Decisions. Journal of International Consumer Marketing, 24(3), 168-185.

Bronfenbrenner, U. (1979). The ecology of human development: experiments by nature and design. Harvard University Press: Cambridge, Mass:.

Bronfenbrenner, U. (Ed.). (1989). Ecological systems theory. (Vol. 6). London: JAI Press.

Browne, E. (2014). Harmful traditional practices in diaspora communities.

Çakir, S. G. (2009). Factors and mechanisms of resilience among Turkish migrant women in the UK. (PhD Dissertation), Middle East Technical University.

Cakir, S. G., \& Yerin Guneri, O. (2011). Exploring the factors contributing to empowerment of Turkish migrant women in the UK. International Journal of Psychology, 46(3), 223-233.

Chung, K., Hong, E., \& Newbold, B. (2013). Resilience among single adult female refugees in Hamilton, Ontario Refuge, 29(1), 65-74.

Clare, M., Goodman, S., Liebling, H., \& Laing, H. (2014). " You Keep Yourself Strong": A Discourse Analysis of African Women Asylum Seekers' Talk about Emotions. Journal of International Women's Studies, 15(1), 83-95. 
Correa-Velez, I., Gifford, S. M., \& Barnett, A. G. (2010). Longing to belong: social inclusion and wellbeing among youth with refugee backgrounds in the first three years in Melbourne, Australia. Social science \& medicine, 71(8), 1399-1408.

De Tona, C., \& Lentin, R. (2010). 'Building a Platform for Our Voices to be Heard': Migrant Women's Networks as Locations of Transformation in the Republic of Ireland. Journal of Ethnic and Migration Studies, 37(3), 485-502. doi: 10.1080/1369183X.2011.526780

Drummond, P. D., Mizan, A., Burgoyne, A., \& Wright, B. (2011). Knowledge of Cardiovascular Risk Factors in West African Refugee Women Living in Western Australia. Journal of Immigrant \& Minority Health, 13(1), 140-148.

Drummond, P. D., Mizan, A., \& Wright, B. (2008). HIV/AIDS knowledge and attitudes among West African immigrant women in Western Australia. Sexual Health, 5(3), 251-259. doi: http://dx.doi.org/10.1071/SH07077

Gillespie, B. M., Chaboyer, W., \& Wallis, M. (2007). Development of a theoretically derived model of resilience through concept analysis. Contemporary Nurse, 25(1-2), 124-135.

Gladden, J. (2012). The coping skills of east African refugees: A literature review. Refugee Survey Quarterly, hds009.

Graham, A. (2011). Strengthening young people's social and emotional wellbeing. Centre for Children and Young People Background Briefing Series, no.7. Lismore:, (7), 1-31.

Guerin, P. B., Allotey, P., Elmi, F. H., \& Baho, S. (2006). Advocacy as a means to an end: assisting refugee women to take control of their reproductive health needs. Women \& health, 43(4), 7-25. 
Hall, V., Thomsen, R. W., Henriksen, O., \& Lohse, N. (2011). Diabetes in Sub Saharan Africa 1999-2011: epidemiology and public health implications. A systematic review. BMC Public Health., 14(11), 564.

Hashimoto-Govindasamy, L., \& Rose, V. (2011). An ethnographic process evaluation of a community support program with Sudanese refugee women in western Sydney. Health Promotion Journal of Australia, 22(2), 107-112.

Hersberger, J. (2013). Resilience theory, information behaviour and social support in everyday life. Paper presented at the Proceedings of the Annual Conference of CAIS/Actes du congrès annuel de I'ACSI.

Hetherington, E. M., \& Stanley-Hagan, M. (2002). Parenting in divorced and remarried families In M. Borntein (Ed.), Handbook of parenting: Being and becoming a parent (Vol. 3). Mahwah, NJ: Lawrence Erlbaum Associates.

Hutchinson, M., \& Dorsett, P. (2012). What does the literature say about resilience in refugee people? Implications for practice. Journal of Social Inclusion, 3(2), 55-78.

Kalathil, J., Bhakta, R., Daniel, O., Joseph, D., \& Trivedi, P. (2011). Recovery and resilience: African, African-Caribbean and South Asian women's narratives of recovering from mental distress. London: Mental Health Foundation and Survivor Research.

Kanyoro, R. A. (2002). Introducing feminist cultural hermeneutics: An African perspective: Pilgrim Press.

Kennan, M. A., Lloyd, A., Qayyum, A., \& Thompson, K. (2011). Settling in: the relationship between information and social inclusion. Australian Academic \& Research Libraries, 42(3), 191-210. 
Khan, S., \& Pedersen, A. (2010). Black African immigrants to Australia: Prejudice and the function of attitudes. Journal of Pacific Rim Psychology, 4(02), 116-129.

Khawaja, N., White, K., Schweitzer, R., \& Greenslade, J. (2008). Difficulties and coping strategies of Sudanese refugees pre, during and postmigration: a qualitative approach. . Transcultural psychiatry, 45(3), 489-512.

Kuo, B. C. (2014). Coping, acculturation, and psychological adaptation among migrants: a theoretical and empirical review and synthesis of the literature. Health Psychology and Behavioral Medicine: an Open Access Journal, 2(1), 16-33.

Lenette, C., Brough, M., \& Cox, L. (2013). Everyday resilience: Narratives of single refugee women with children. Qualitative Social Work, 12(5), 637-653.

Lloyd, A. (2014). Building Information Resilience: How do Resettling Refugees Connect with Health Information in Regional Landscapes-Implications for Health Literacy. Australian Academic \& Research Libraries, 45(1), 48-66.

Logan, B. I. (2009). The reverse and return transfer of technology (RRTT): Towards a comprehensive model of the migration of African experts. International migration, 47(4), 93-127.

Mays, N., \& Pope, C. (2000). Qualitative research in health care: Assessing quality in qualitative research. BMJ: British Medical Journal, 320(7226), 50.

McGarry, J., Simpson, C., \& Hinchliff-Smith, K. (2011). The impact of domestic abuse for older women: a review of the literature. Health \& social care in the community, 19(1), 3-14. 
McQuilten, Z., Waters, N., Polonsky, M., \& Renzaho, A. (2014). Blood donation by African migrants and refugees in Australia: the role of demographic and socio-economic factors. Vox sanguinis, 106(2), 137-143.

Mental Health Foundation of Australia, M. (2005). Embrace the future resiliency resource Centre. Australia: Retrieved from www.embracethefuture.org.au/resiliency/what is resiliency.htm.

Moher, D., Liberati, A., Tetzlaff, J., \& Altman, D. G. (2009). Preferred reporting items for systematic reviews and meta-analyses: the PRISMA statement. Annals of internal medicine, 151(4), 264269.

Murray, L., Windsor, C., Parker, E., \& Tewfik, O. (2010). The experiences of African women giving birth in Brisbane, Australia. Health care for women international, 31(5), 458-472.

Mwanri, L., Hiruy, K., \& Masika, J. (2012). Empowerment as a tool for a healthy resettlement: a case of new African settlers in South Australia. International Journal of Migration, Health and Social Care, 8(2), 86-97.

Neblett Jr, E. W., Hammond, W. P., Seaton, E. K., \& Townsend, T. G. (2010). Underlying mechanisms in the relationship between Africentric worldview and depressive symptoms. Journal of counseling psychology, 57(1), 105.

Obrist, B., \& Büchi, S. (2008). Stress as an idiom for resilience: health and migration among sub-Saharan Africans in Switzerland. Anthropology and Medicine, 15(3), 251-261. 
Ogunsiji, O. O., Wilkes, L., Jackson, D., \& Peters, K. (2011). Suffering and smiling: West African immigrant women's experience of intimate partner violence. Journal of clinical nursing, 21(11-12), 1659 1665.

Orton, L., Griffiths, J., Green, M., \& Waterman, H. (2012). Resilience among asylum seekers living with HIV. BMC public health, 12(1), 926.

Pavlish, C. (2005). Action responses of Congolese refugee women. Journal of Nursing Scholarship, 37(1), 10-17.

Polonsky, M., Brijnath, B., \& Renzaho, A. (2011). "They don't want our blood": social inclusion and blood donation among African migrants in Australia. Social science \& medicine, 73(2 ), 336-342.

Poncian, J. (2015). The persistence of western negative perceptions about Africa: Factoring in the role of Africans. Journal of African Studies and Development, 7(3), 72-80.

Pottie, K., Ng, E., Spitzer, D., Mohammed, A., \& Glazier, R. (2008). Language proficiency, gender and selfreported health: an analysis of the first two waves of the longitudinal survey of immigrants to Canada. Can J Public Health, 99(6), 505-510.

Pulvirenti, M., \& Mason, G. (2011). Resilience and survival: Refugee women and violence. Current Issues Criminal Justice, 23, 37-52.

Rashid, R., \& Gregory, D. (2014). 'Not Giving Up on Life': A Holistic Exploration of Resilience among a Sample of Immigrant Canadian Women. Canadian Ethnic Studies, 46(1), 197-214.

Remennick, L. (2005). Immigration, gender, and psychosocial adjustment: A study of 150 immigrant couples in Israel. Sex Roles, 53(11-12), 847-863. 
Robinson, L., \& Spilsbury, K. (2008). Systematic review of the perceptions and experiences of accessing health services by adult victims of domestic violence. Health \& social care in the community, 16(1), 16-30.

Sanchez, M., Dillon, F. R., Concha, M., \& De La Rosa, M. (2014). The Impact of Religious Coping on the Acculturative Stress and Alcohol Use of Recent Latino Immigrants. Journal of religion and health, 1-19.

Schweitzer, R., Greenslade, J., \& Kagee, A. (2007). Coping and resilience in refugees from the Sudan: a narrative account. Australian and New Zealand Journal of Psychiatry, 41(3), 282-288.

Schweitzer, R., Melville, F., Steel, Z., \& Lacherez, P. (2006). Trauma, post-migration living difficulties, and social support as predictors of psychological adjustment in resettled Sudanese refugees. Australian and New Zealand Journal of Psychiatry, 40, 179-187

Shakespeare-Finch, J., \& Wickham, K. (2010). Adaptation of Sudanese refugees in an Australian context: investigating helps and hindrances. International migration, 48(1), 23-46.

Sherwood, K., \& Liebling-Kalifani, H. (2013). A grounded theory investigation into the experiences of African women refugees: Effects on resilience and identity and implications for service provision. Journal of International Women's Studies, 13(1), 86-108.

Statistics Canada. (2009). Immigration in Canada: A portrait of the foreign-born population, 2006 census: immigrants came from many countries. Retrieved 02 June 2015 http://www12.statcan.ca/census-recensement/2006/as-sa/97-557/p5-eng.cfm 
Steffen, P., \& Merrill, R. (2011). The association between religion and acculturation in Utah Mexican immigrants. Mental Health, Religion \& Culture, 14(6), 561-573.

Tempany, M. (2009). What research tells us about the mental health and psychosocial wellbeing of Sudanese refugees: a literature review. Transcultural psychiatry, 46(2), 300-315.

United Kingdom National Statistics. (2009). Home Office Statistical Bulletin. Control of Immigration: Statistics United Kingdom 2008 (Publication no. http://webarchive.nationalarchives.gov.uk/20110218135832/rds.homeoffice.gov.uk/rds/pdfs09 /hosb1409.pdf). Retrieved 02 June 2015

United Nations Department of Economic and Social Affairs Population Division. (2009). International Migration Report 2006: A global assessment: United Nations New York.

United Nations High Commissioner for Refugees. (2012). A Year in Crises: UNHCR Global Trends 2011 (Publication no. http://www.unhcr.org/4fd6f87f9.html).

van der Ham, A. J., Ujano-Batangan, M. T., Ignacio, R., \& Wolffers, I. (2014). Toward healthy migration: An exploratory study on the resilience of migrant domestic workers from the Philippines. Transcultural psychiatry, 51(4), 545-568.

Venters, H., Adekugbe, O., Massaquo, I. J., Nadeau, C., Saul, J., \& Gany, F. (2011). Mental health concerns among African immigrants. Journal of Immigrant \& Minority Health, 13(4), 795-797.

Webb, M. (2013). Experiences of African refugees who transition to university: a question of resilience. (Bachelor of Science (Psychology) Honours), Edith Cowan University. Retrieved from http://ro.ecu.edu.au/theses hons/92 
Wise, S. (2003). Family structure, child outcomes and environmental mediators: An overview of the development in diverse families study. 3-42.

Table 1. Peer-reviewed literature exploring resilience of African migrants [ $\mathrm{n}=9]$

\begin{tabular}{|c|c|c|c|c|}
\hline $\begin{array}{l}\text { First author } \\
\text { (year) }\end{array}$ & $\begin{array}{l}\text { Country/Settin } \\
\text { g }\end{array}$ & $\begin{array}{l}\text { Populatio } \\
\text { n }\end{array}$ & Design/Method & Aims \\
\hline $\begin{array}{l}\text { Anderson \& } \\
\text { Doyal, } 2004\end{array}$ & England & $\begin{array}{l}62 \text { women } \\
\text { from } 11 \\
\text { African } \\
\text { countries } \\
\text { receiving } \\
\text { HIV } \\
\text { treatment } \\
\text { in five } \\
\text { specialist } \\
\text { clinics in } \\
\text { London }\end{array}$ & $\begin{array}{l}\text { Qualitative - } \\
\text { self-administered } \\
\text { questionnaire for } \\
\text { demographics and } \\
\text { in-depth semi- } \\
\text { structured } \\
\text { interviews }\end{array}$ & $\begin{array}{l}\text { Investigate the } \\
\text { particular } \\
\text { needs and } \\
\text { experiences of } \\
\text { African women } \\
\text { living with HIV } \\
\text { in the UK }\end{array}$ \\
\hline $\begin{array}{l}\text { Bentley, Ahmad } \\
\text { \& Thoburn, } \\
2014\end{array}$ & $\begin{array}{l}\text { United States of } \\
\text { America }\end{array}$ & $\begin{array}{l}59 \text { Somali } \\
\text { Muslim } \\
\text { refugees } \\
\text { from East } \\
\text { Africa }\end{array}$ & $\begin{array}{l}\text { Quantitative - } \\
\text { Questionnaire/Surv } \\
\text { ey }\end{array}$ & $\begin{array}{l}\text { Examine the } \\
\text { influence of } \\
\text { religiosity on } \\
\text { the relationship } \\
\text { between } \\
\text { traumatic } \\
\text { exposure and } \\
\text { post-traumatic } \\
\text { stress disorder } \\
\text { symptom } \\
\text { severity }\end{array}$ \\
\hline $\begin{array}{l}\text { Khawaja, } \\
\text { White, } \\
\text { Schweitzer \& } \\
\text { Greenslade,200 } \\
8\end{array}$ & Australia & $\begin{array}{l}23 \\
\text { Sudanese } \\
\text { refugees } \\
{[12 \mathrm{~F}]}\end{array}$ & $\begin{array}{l}\text { Qualitative - } \\
\text { Semi-structured } \\
\text { interviews }\end{array}$ & $\begin{array}{l}\text { Examine the } \\
\text { pre-migration, } \\
\text { transit and } \\
\text { post-migration } \\
\text { descriptions of } \\
\text { the participants } \\
\text { to determine } \\
\text { their difficulties } \\
\text { and how they } \\
\text { coped and } \\
\text { adapted. }\end{array}$ \\
\hline $\begin{array}{l}\text { Lenette, } \\
\text { Brough \& Cox, } \\
2013\end{array}$ & Australia & $\begin{array}{l}4 \text { single } \\
\text { Sudanese } \\
\text { refugee } \\
\text { women } \\
\text { with } \\
\text { children } \\
\text { from } \\
\text { diverse }\end{array}$ & $\begin{array}{l}\text { Qualitative - } \\
\text { Ethnography and } \\
\text { in-depth interviews }\end{array}$ & $\begin{array}{l}\text { Explore } \\
\text { resilience as a } \\
\text { process during } \\
\text { everyday } \\
\text { activities } \\
\text { among the } \\
\text { women }\end{array}$ \\
\hline
\end{tabular}




\begin{tabular}{|c|c|c|c|c|}
\hline & & $\begin{array}{l}\text { African } \\
\text { countries } \\
\text { [Congo, } \\
\text { Burundi } \\
\text { and } \\
\text { Sudan] } \\
\end{array}$ & & \\
\hline Lloyd, 2014 & Australia & $\begin{array}{l}20 \\
\text { refugees } \\
\text { mainly } \\
\text { from the } \\
\text { North, } \\
\text { East and } \\
\text { Central } \\
\text { African } \\
\text { countries } \\
{[13 \mathrm{~F}]}\end{array}$ & $\begin{array}{l}\text { Qualitative - } \\
\text { Face to face } \\
\text { semi-structured } \\
\text { interviews }\end{array}$ & $\begin{array}{l}\text { Explore } \\
\text { participants' } \\
\text { experiences of } \\
\text { new health } \\
\text { environment in } \\
\text { developing } \\
\text { health literacy } \\
\text { practice } \\
\text { including how } \\
\text { they construct } \\
\text { and } \\
\text { disseminate } \\
\text { information. }\end{array}$ \\
\hline $\begin{array}{l}\text { Obrist \& Büchi, } \\
2008\end{array}$ & Switzerland & $\begin{array}{l}20[9 \mathrm{~F}] \\
\text { sub- } \\
\text { Saharan } \\
\text { African } \\
\text { people }\end{array}$ & $\begin{array}{l}\text { Qualitative - } \\
\text { Case studies and } \\
\text { group discussions }\end{array}$ & $\begin{array}{l}\text { Explore } \\
\text { resilience as a } \\
\text { process during } \\
\text { everyday } \\
\text { activities } \\
\text { among the } \\
\text { women }\end{array}$ \\
\hline $\begin{array}{l}\text { Orton, Griffiths, } \\
\text { Green \& } \\
\text { Waterman, } \\
2012\end{array}$ & United Kingdom & $\begin{array}{l}26 \text { Asylum } \\
\text { seekers } \\
{[16 \mathrm{~F}]} \\
\text { from } 7 \\
\text { African } \\
\text { countries }\end{array}$ & $\begin{array}{l}\text { Qualitative - } \\
\text { Focus groups and } \\
\text { interviews }\end{array}$ & $\begin{array}{l}\text { Explore } \\
\text { experiences of } \\
\text { life as an } \\
\text { asylum seeker } \\
\text { living with HIV } \\
\text { in UK. }\end{array}$ \\
\hline $\begin{array}{l}\text { Schweitzer, } \\
\text { Greenslade \& } \\
\text { Kagee, } 2007\end{array}$ & Australia & $\begin{array}{l}13[4 \mathrm{~F}] \\
\text { Sudanese } \\
\text { refugees }\end{array}$ & Qualitative & $\begin{array}{l}\text { Identify and } \\
\text { explain the } \\
\text { coping and } \\
\text { resilience of } \\
\text { participants }\end{array}$ \\
\hline $\begin{array}{l}\text { Shakespeare- } \\
\text { Finch \& } \\
\text { Wickham, } 2010\end{array}$ & Australia & $\begin{array}{l}12[6 \mathrm{~F}] \\
\text { Sudanese } \\
\text { refugees }\end{array}$ & $\begin{array}{l}\text { Qualitative - } \\
\text { Semi-structured } \\
\text { interviews }\end{array}$ & $\begin{array}{l}\text { What } \\
\text { helped/hindere } \\
\text { d participants } \\
\text { in adapting } \\
\text { while in Sudan, } \\
\text { en-route and in } \\
\text { Australia? }\end{array}$ \\
\hline
\end{tabular}




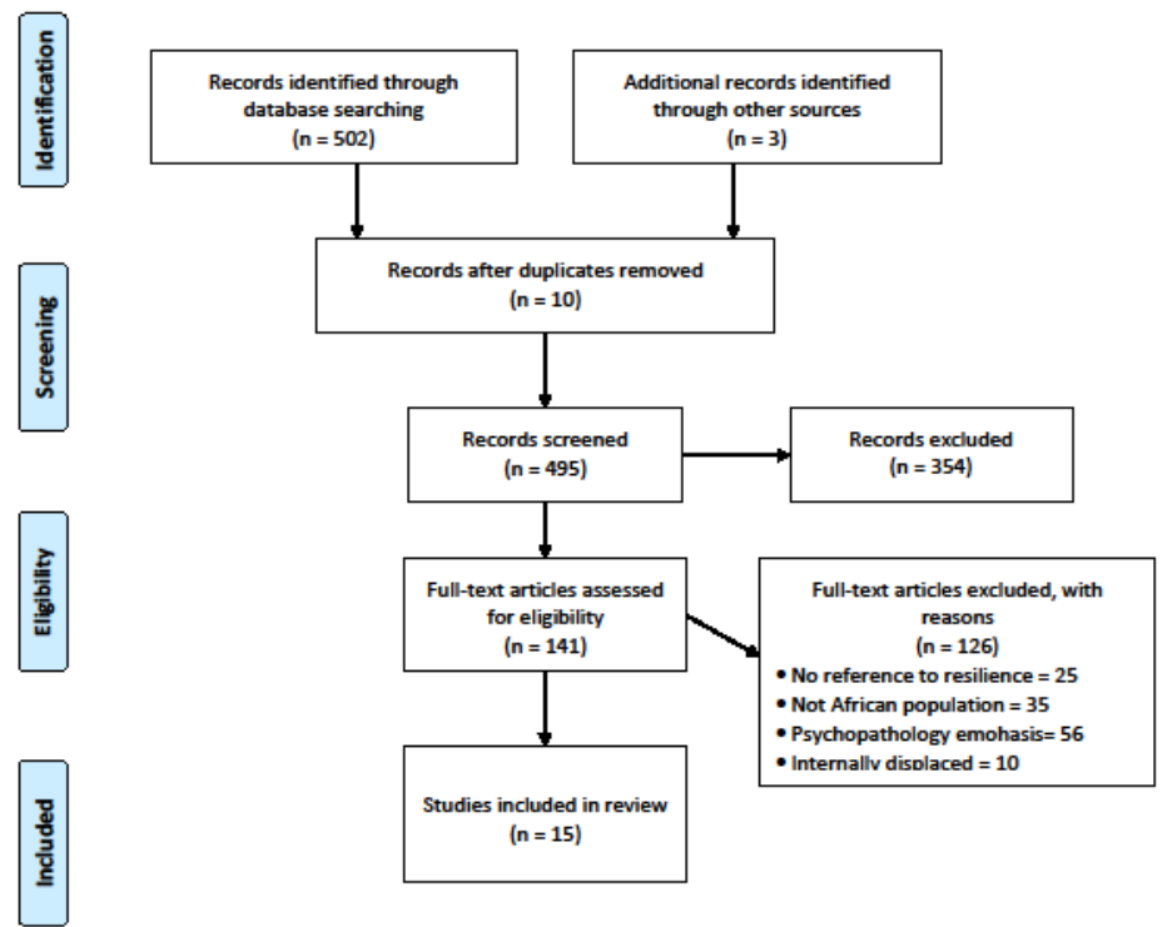

From: Moher D, Uberat A, Tetziar J, Altman DG, The PRISMA Group (2009). Preferred Reporting hems for Systematic Reviews and MetaAnalyses: The PRISMA Statement. PLOS Med 6(6): e1000097, dol:10. 1371/loumal pmedi000097

For more information, visit woww prisma-statement. ore.

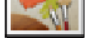

Slide1.TIF 